\title{
What Is Meant by Inclusive Education? Perceptions of Turkish Teachers towards Inclusive Education
}

\author{
Sevda Katıtaş, ${ }^{1, *} \&$ Başak Coşkun ${ }^{2}$ \\ ${ }^{1}$ Ministry of National Education, Cumhuriyet Secondary School, Ankara, Turkey \\ ${ }^{2}$ Ministry of National Education, Sümer Science High School, Kayseri, Turkey \\ *Correspondence: Ministry of National Education, Cumhuriyet Secondary School, Ankara, Turkey. E-mail: \\ sasevda@gmail.com
}

Received: July 17, 2020

Accepted: September 18, 2020

Online Published: October 10, 2020

doi:10.5430/wje.v10n5p18

URL: https://doi.org/10.5430/wje.v10n5p18

\begin{abstract}
The aim of this study was to determine the perceptions of teachers in Turkey towards inclusive education through metaphors. Phenomenology was adopted in this research. The study group of the research consisted of 120 teachers working in public schools in Turkey in 2019-2020 academic year. Snowball sampling, criterion sampling and maximum diversity sampling methods were used to determine the study group. Content analysis was applied to the data. As a result of the research, it was revealed that Turkish teachers considered inclusive education as a process that required patience and exertion and that this education was an indispensable need for the student with special needs. It was concluded that suitable educational support should have been given to the students with special needs according to their individual needs. It was also concluded that it was important for students with special needs to share the same learning environment in an integrity without separating them from their peers who had 'normal' academic and social development. In addition, it was emphasized that students with special needs should have been accepted with their own behaviours and characteristics in the learning environments they were in and it was important to turn these differences into opportunities for the benefit of the student.
\end{abstract}

Keywords: inclusive education, students with special needs, metaphor

\section{Introduction}

Education is vital for children with special needs like all children both in terms of having a profession and participating in social life. Such that, attending school has an important place in completing the personality of the child and being an individual. In addition, social relations established both in social life and educational environments can change the situation of individuals with special needs and indirectly contribute to protecting their rights. For example, other children who communicate with children who have special needs in inclusive classrooms can learn not to be biased towards these children and respect differences. Therefore, it is possible to say that inclusive education has an indispensable role in promoting equal and fair societies.

One of the ways to provide education to the students with special needs is implementing inclusive education. Inclusive education sees all children as equal members of an educational community and supports their full participation in the general education system. Inclusive education requires recognizing and protecting the rights of all children and understanding human diversity as a rich resource. Inclusive education is an educational approach that is free from discriminatory beliefs, attitudes, and practices. Inclusive and integrative values should be put into action to ensure that all children participate in education and develop in inclusive education (Cologon, 2013).

Farrell $(2000,154)$ defines inclusive education as 'education service in which students with special needs participate in the general education system with their normally developing peers, take an active role in school life, and where they are seen as valuable and integral members of the school'. Similarly, Rafferty, Boettcher, and Griffin $(2001,266)$ explains inclusive education as 'the process of educating children with special needs in general education classes by using the services and support they need'.

According to Loreman and Deppeler (2002), the main purpose of inclusive education is not only to accept students with special needs but also to be ready to meet them with all their differences. To achieve this goal, it is not enough to 
make changes only in terms of structure and functioning in schools. At this point, the attitudes, beliefs and values of school management, teachers and employees on this issue become important. Uditsky (1993), with similar thoughts, emphasizes that students with special needs (regardless of special requirement type and grade) in inclusive classes should be valuable members of their classes. According to the author, students in inclusive classrooms continue their education in general education classes (they are supported individually when they need), follow the curriculum (they benefit from individualized education programs in the least restrictive educational environments), make friends, contribute to the learning of the whole class by promoting a more tolerant classroom atmosphere and they participate actively in all stages of school life in accordance with their competences and interests.

There are some issues that should be taken into consideration for students with special needs to see themselves as part of the environment they are in and therefore to feel valuable. These issues include preparing programs to meet the needs of students or adapting existing programs in line with student needs, using effective methods and techniques in teaching and benefiting from support services both in and outside the classroom (Smith, Polloway, Patton, \& Dowdy, 2014). De Boer, Pijl, and Minnaert (2011) state that issues such as education, resources, legislation, and teachers often come to the fore in research on inclusive education. Among them, especially teachers are considered to play a key role in the development and implementation of inclusive education (Meijer, 2003; Norwich, 1994). According to various studies examining the attitudes of teachers towards inclusive education, it was observed that some teachers had positive attitudes (Abbott, 2006; Avramidis \& Norwich, 2002; Marshall, Ralph, \& Palmer, 2002). Some teachers, on the other hand, had serious reservations about the implementation of inclusive education due to the problems experienced (Florian, 1998; Pearman, Huang, \& Mellblom, 1997; Ring \& Travers, 2005).

Various factors may influence teachers' attitudes towards the inclusion of children with special needs. According to De Boer et al. (2011) teachers' attitudes generally differ according to the type of special needs the child has. In a study conducted by Avramidis, Bayliss, and Burden (2000), it was found that teachers had more negative attitudes towards students with emotional and behavioural difficulties compared to other children with special needs. Apart from these, variables such as experience related to inclusive education (Moberg, 2003) and class size (Anderson, Klassen, \& Georgiou, 2007; Rose, 2001; Smith \& Smith, 2000) might have effects on teachers' attitudes.

While talking about inclusive education, it is also important to emphasize not only the academic objectives but social development of students as well. The aim of the parents to demand inclusive education for their children with special needs is to ensure their children's social development and increase their chances of communicating and interacting with their peers (De Boer et al., 2011; Sloper \& Tyler, 1992). According to parent reports, peer relationships established in general education classes have positive effects on children with special needs in terms of their behaviours and social interactions (Koster, Pijl, Houten, \& Nakken, 2007).

Although inclusive education has positive effects on children with special needs, many researchers state that there are some risks in this field both for students with special needs and other students. When evaluated from their perspective, children with special needs who benefit from inclusive education are ignored and mocked by other peers in the class (Cole \& Meyer, 1991). Similarly, Wiener and Harris (1989) explain that students with special needs, especially those with learning problems, are rejected and neglected by their peers. Research on social acceptance shows that students with special needs in general education classes receive less acceptance than their classmates without special needs (Freeman \& Alkin, 2000), they generally have a lower social status than their classmates (Pavri \& Luftig, 2001; Kuhne $\&$ Wiener, 2000) and they show that they lead a more isolated life than their peers in terms of sociability (Margalit \& Efrati, 1996).

Some practices in inclusive education may also have some negative aspects for students who do not have special needs. For example, placing students who display uncontrollable behaviours in general education classes may negatively affect other students both academically and socially (Kauffman, Lloyd, Baker, \& Riedel, 1995). In addition, teachers who have students with special needs in their class may fail to provide appropriate support and service to meet the needs of these students (Shanker, 1995). In this context, the successful inclusion of students with special needs in schools within the general education system requires reform efforts to meet their different needs (Koh \& Robertson, 2003). In schools that provide services to students with special needs, buildings or departments should be designed in such a way that all students can access and move freely (Pivik, Mccomas, \& Laflamme 2002), curriculum should be revised to ensure effective and efficient participation of students and differenciated according to students' needs (Martinez \& Humphreys, 2006).

Educating students with special needs in regular classrooms has been legally adopted in Turkey by Children with Special Educational Needs Law enacted in 1983. As of this date, the idea of organizing schools and classes to include all students and making adaptations to meet the individual needs of students has been increasingly adopted with the 
spread of inclusive education. In this education system, it is emphasized that each child should be supported without being left behind (Kargın, Güldenoğlu, \& Şahin, 2010). For a successful inclusive education, all school employees, especially principal, should take a welcoming and supportive attitude towards these students. Because children with special needs and their families constantly interact with teachers, school principals and other school staff by the school enrolment phase during which many problems start to emerge. There are many studies (Doğaroğlu \& Dümenci, 2015; Sönmez, Alptekin, \& Bıçak, 2019; Özkubat, Sanır, Töret, \& Babacan, 2016; Toy \& Duru, 2016) demonstrating that teachers play an important role in the effectiveness of inclusive education. From this point of view, it is possible to say that it is very important to reveal teachers' perceptions about inclusive education. In this context, it was aimed in this study to determine the perceptions of teachers in Turkey towards inclusive education through metaphors.

\section{Method}

\subsection{Research Design}

Phenomenological research design, which is one of the qualitative research designs, was applied in this study. Phenomenological research design focuses on the cases that we are aware of but do not have detailed information on (Yıldırım \& Şimşek, 2008). The phenomenon in this study is the public-school teachers' perceptions about inclusive education.

\subsection{Study Group}

The study group of the research consisted of 120 teachers working in public schools in Ankara and Kayseri provinces of Turkey in 2019-2020 academic year. Snowball sampling, criterion sampling and maximum diversity sampling methods were used to determine the study group. Accordingly, it was started by the names known to the researchers and new names were reached using the snowball technique. While determining the participants, teachers with special needs students in their class were included in the study by using the criterion sampling approach. To reach the maximum diversity, the research was conducted with teachers who was working at different school levels (kindergarten, primary school, secondary school, and high school) and differed in terms of gender, professional seniority, and branch. A balance was achieved between school levels, gender, professional seniority, and branches of the teachers. Theoretical sampling approach was adopted when deciding on sample size. After 120 people were included in the study, the researchers decided that they had reached the saturation (Shenton, 2004) and stopped the process of including participants in the sample. 39 people were eliminated from the sample for not using the metaphor correctly in the form or leaving the questions partially or completely blank. Data analysis was performed on 81 participants. Accordingly, 20 participants were working in kindergarten, 20 participants were working in primary school, 21 participants were working in secondary school and 20 participants were working in high school. 46 of the participants were women and 35 of the participants were men. The work experience of the participants varied between 1 year and 20 years.

\subsection{Data Collection}

'Teacher Interview Form for the Examination of Teachers' Opinions about Inclusive Education through Metaphors' was used as data collection tool. In the first part of the form, there are questions about the personal information of the teachers and in the second part, there is a statement aiming to reveal the teachers' metaphor perceptions about inclusive education. There are several researches applying metaphors as a research tool, as metaphors give valuable data for defining perceptions (Noyes, 2004; Saban, Koçbeker, \& Saban, 2005). In educational terms, metaphors are used as an effective tool to make meaningful connections between personal perceptions and educational theories (as quoted in Leavy, McSorley, \& Bote, 2007).

In the second part of the form, a question was asked to the participants as: 'Inclusive education is like... Because...'. In metaphor studies, the concept of 'like' is used to explain the relationship between the subject of the metaphor and the source of the metaphor while the concept of 'because' is used to give a reason for metaphor (Saban, 2009). Data collection forms were given to the participants directly by the researchers and were collected by them.

\subsection{Data Analysis}

The data obtained with the forms were subjected to content analysis, which included determining patterns, coding, and categorizing steps (Yıldırım \& Şimşek, 2008). Following these steps, categories were created by reviewing the metaphors produced for each concept and the expressions of the participants about why they used these metaphors. In other words, metaphors produced by teachers were grouped under specific categories for each concept. Frequency (f) values for each metaphor was calculated in each category. 


\subsection{Trustworthiness}

The relevant literature was scanned, and the tests used to reveal metaphors were utilized to ensure trustworthiness. The questions in the data collection form were examined by two field experts of inclusive education, and they were revised according to their comments on the form. Before applying the data collection tool to the study group, a pilot study was conducted with three teachers. In the research, the data analysis process, namely, how the categories were created from the data was clearly explained. Direct quotations from the teachers' own statements were included in interpretation of the findings. The participants were coded as T1, T2, T3 etc. The categories were generated independently by two researchers and their results were compared to ensure reliability in the research. As a result of the comparison, it was seen that similar findings were obtained. In addition, the opinions of the two field experts were asked to check whether the metaphors under the created categories represent the category in question. After their comments on the categories were revised, the researchers came to an agreement on the final categories.

\section{Findings}

Within the scope of the research, the metaphors used by teachers regarding inclusive education were categorized and gathered under nine categories. The reasons written by teachers about metaphors were used in the creation of categories. Teachers used 62 metaphors in total. These metaphors in each category are given in Table 1.

Table 1. Metaphors Used by Teachers Regarding Inclusive Education

\begin{tabular}{|c|c|c|}
\hline Categories & Metaphors & Opinions (f) \\
\hline Patience and Exertion & $\begin{array}{l}\text { Mineral Exploration (3), Tough Nut (2), Bottomless Well (2), } \\
\text { Pathway (2), Mandala (1), Preparing for the Olympics (1), } \\
\text { Pomegranate Extraction (1), Night (1), Digging the Well with } \\
\text { Needle (1), Stone in Stream (1), Honey Production (1), Butterfly in } \\
\text { Cocoon (1), Swimming in the Choppy Sea (1), Climbing a } \\
\text { Branchless Tree (1), Equation (1), Craft (1), Wheat Growing (1), } \\
\text { Mine (1), Seasons (1), Baby Care (1) }\end{array}$ & 25 \\
\hline Affection & Mother (4), Family (2), Marriage (1), Flower Growing (1) & 8 \\
\hline Proper Educational Support & $\begin{array}{l}\text { Coal Processing (2), Money (1), Maze (1), Crutches (1), } \\
\text { Bomb Ready to Explode (1), Elevator (1), Space Research (1), } \\
\text { Yoghurt Fermentation (1), Landscaper (1), Garden Maintenance (1), } \\
\text { Archery (1), Iceberg (1), Driving License Course (1), Factory (1) }\end{array}$ & 15 \\
\hline Slow and Gradual Progress & Stair Step (1), Crawling Baby (1), Nature (1) & 3 \\
\hline Integration & $\begin{array}{l}\text { Travel (1), Puzzle (1), Baby's Birth (1), Flower Arrangement (1), } \\
\text { Chain (1), Cooking Rice (1) }\end{array}$ & 6 \\
\hline Understanding Differences & $\begin{array}{l}\text { Flower Garden (2), Gardener (2), Reading Books in Mother Tongue } \\
\text { (1), Rainbow (1) }\end{array}$ & 6 \\
\hline $\begin{array}{l}\text { Equal Access to } \\
\text { Opportunities }\end{array}$ & Scale (2) & 2 \\
\hline Need & $\begin{array}{l}\text { First Aid (2), Water (2), Point in Exclamation Point (1), Air (2), } \\
\text { Light (1), Drug (1) }\end{array}$ & 9 \\
\hline Dealing in vain & $\begin{array}{l}\text { Rowing Against the Current (4), Hollow Bucket (1), Unfair Race } \\
\text { (1), Patched Fabric (1) }\end{array}$ & 7 \\
\hline
\end{tabular}

According to Table 1, it is seen that teachers mostly evaluate the inclusive education by creating metaphors related to 'patience and exertion ( $\mathrm{f}=25)$ ' and 'proper educational support ( $\mathrm{f}=15)$ ' categories. These are followed by 'need ( $\mathrm{f}=9)$ ', 'affection ( $\mathrm{f}=8)$ ', 'dealing in vain $(\mathrm{f}=7)$ ', 'integration $(\mathrm{f}=6)$ ', 'understanding differences $(\mathrm{f}=6)$ ', 'slow and gradual progress $(\mathrm{f}=3)$ ' and 'equal access to opportunities $(\mathrm{f}=2)$ ' categories respectively. Explanations for these categories are discussed below.

\subsection{Patience and Exertion}

This category included the views of the participants emphasizing that inclusive education was a sensitive and difficult process and therefore required patience and exertion. For example, a classroom teacher working in primary school used the butterfly in cocoon metaphor for inclusive education and said, 'Exertion is required for the butterfly in the cocoon to reach the required strength and to sprout its wings. It is necessary to wait patiently' (T36). 


\subsection{Proper Educational Support}

It was found out that it was important to present a learning environment that was suitable for the individual needs of the student in inclusive education and that the desired results could be achieved by using appropriate teaching methods and materials for the student. Accordingly, a math teacher working in secondary school said, 'Inclusive education is like the coal processing. Because, although it may seem worthless among the diamonds, it will shine like diamonds when processed' (T46). A school counsellor working in high school explained the inclusive education with the words 'In inclusive education, students may have characteristics that are waiting to be discovered, just like an iceberg underwater. If the teacher gives training to reveal these features, good results surprising everyone can emerge from iceberg underwater.' (T66) by using the iceberg metaphor.

\section{$3.3 \mathrm{Need}$}

It was emphasized that inclusive education was an indispensable need for the student relying on this education and it was important to meet this basic need. A social sciences teacher used the water metaphor and explained the reason as such; 'Students with special needs in general classes need inclusive education for their emotional, behavioural and academic development. This education is basic and indispensable need for them, like water.' (T11).

\subsection{Affection}

It was seen that participants evaluated the inclusive education within the framework of interest, affection, and volunteering. This category included opinions that point out the importance of teachers' showing their affection for students and making them feel valuable. In this category, a kindergarten teacher said, 'Inclusive education is like a mother. Because it requires warmth and sincerity of a mother' (T3).

\subsection{Dealing in Vain}

It was revealed that some participants had the opinion that the structure and functioning of inclusive education could not be understood by the teachers adequately, that sufficient conditions could not be achieved in schools and classrooms for this education and therefore the desired success could not be achieved in practice. For example, a classroom teacher likened inclusive education to rowing against the current and explained his opinion as follows: 'I think that the teachers who have not been educated about inclusive education in public schools do not know the students with special needs well, cannot reach their levels and therefore these students waste their time in the classrooms' (T42).

\subsection{Integration}

It was emphasized that it was important for students with special needs in inclusive education to share the same learning environment in an integrity without being separated from their peers in cognitive, social and educational practices. Under this category, participants used metaphors hinting that it would be beneficial for students with special needs and other students to benefit from all social, cultural, and educational activities with their peers. In this context, an English teacher working in high school likened inclusive education to the journey and stated that 'Passengers learn new things from each other on this road together' (T1).

\subsection{Understanding Differences}

In this category, it was emphasized that student with special needs had unique behaviours and characteristics differentiating them from other students. In addition, there were opinions that these differences should have been accepted and converted into educational opportunities in a way that was in the best interest of the student. For example, a kindergarten teacher who compared inclusive education to the flower garden explained the reason with the words 'Each flower is different and beautiful in flower garden. Students with special needs beautify their environment with their differences in inclusive education.' (T7).

\subsection{Slow and Gradual Progress}

This category consisted of the views in which the student was taken to the centre and pointed out the importance of advancing in small steps according to the individual needs of the student. A classroom teacher explained her opinion in this category with the words 'Inclusive education is like nature. Because nature constantly renews and changes itself. This constant change is happening gradually. Although there is a slow progress in inclusive education, it definitely causes a positive change.' (T71).

\subsection{Equal Access to Opportunities}

In this category, it was marked that all students, including students with special needs should have been assured to benefit equally from the educational opportunities. Similarly, there were opinions that emphasized the necessity of 
full and complete utilization of the right of education for students with special needs. In this context, a physics teacher expressed his opinion as 'Inclusive education is like a scale. Because to provide equal education to disadvantaged individuals in the same environment as other students and to improve their social communication, one must try to establish a constant balance between the two student groups.' (T58).

\section{Discussion}

In this study, the categories of patience and exertion and proper educational support were the categories in which teachers mostly used metaphors in explaining inclusive education. With the patience and exertion category, it was revealed that inclusive education was a difficult process requiring precision and it was emphasized that it called for patience and exertion. Similar results emerged in Uysal's (2004) study. The author evaluated the opinions of the teachers about inclusive education and most of the participants stated that inclusive education was tiring because it demanded a lot of individual work and dedication. In another similar study conducted with teacher candidates by Kayıll, Koçyiğit, Doğru, and Çiftçi (2010), it was revealed that participants considered the inclusive education beneficial for both students with special needs and other peers, but they considered it a very difficult and tiring process for the teacher. It can be said that these views of teachers about inclusive education arise from negative experiences, difficulties, or lack of sufficient knowledge about this issue in schools.

The adversities, challenges or equipment inadequacies experienced by teachers about inclusive education may affect their attitudes on this issue negatively. Because in many studies (Alver, Bozgeyikli, \& Işıklar, 2011; De Boer et al., 2011; Gök \& Erbaş, 2011; Gözün \& Y1kmış, 2004; Karasu, 2019), it was found that teachers' lack of sufficient knowledge about inclusive education had a negative effect on their attitudes towards inclusive practices. In this regard, Blanton, Pugach, and Florian (2011) emphasized that teachers' views towards supporting inclusive practices increased gradually, but research had generally shown that they felt unprepared in this process, were anxious to cope with the problems and thus were reluctant to place students with special needs in their classrooms. Similarly, Monteiro, Kuok, Correia, Forlin, and Teixeira (2019) stated that teachers find themselves insufficient in terms of knowledge and skills when working with students with special needs in their classrooms and this prevents the success of inclusive practices.

The category of proper educational support was another category in which teachers mostly used metaphors in explaining inclusive education. In this category, it was emphasized that it is important to organize the learning environment in inclusive education to meet the individual needs of the student with special needs and to support the student with appropriate methods and materials. There are studies in the literature that reveal similar findings. For example, Odom, Buysse, and Soukakou (2012) and Watkins (2012) linked the effectiveness of inclusive practices to the provision of special teaching methods according to the individual needs of students. In other words, to facilitate the learning of students with special needs, the individualized education program should be employed rather than the general education program (Pit-ten Cate, Markova, Krischler, \& Krolak-Schwerdt, 2018). Based on this, it can be said that teachers' attitudes and behaviours in inclusive education and their competence in providing appropriate educational support are important for the success of this process. Borg, Hunter, Sigurjonsdottir, and S. D'Alessio (2011) stated that teachers should have had a positive attitude and appropriate knowledge, skills and understanding for this education to be effective in inclusive education. Similarly, De Boer et al. (2011) revealed that teachers' attitudes towards students with special needs were related to their competencies.

In the research, teachers frequently used metaphors in the categories of need, affection, integration and understanding differences in the description of inclusive education. In the category of need, it was pointed out that inclusive education was an indispensable basic need for the student with special needs. In the affection category, it was emphasized that inclusive education was a process that could be carried out with interest and affection. When these two categories are considered together, it is revealed that teachers' perspectives, attitudes, and behaviours to the education of students with special needs are important. It can be said that these attitudes and behaviours of teachers are affected by many factors such as professional experience, student's special needs type, class size, teacher self-efficacy and adequacy of teaching materials. For example, researchers such as Schmidt and Vrhovnic (2015) and Boyle, Topping, and Jindal-Snape (2013) with regard to professional experience reached the conclusion that the teachers in the 20-30 age group had a more positive attitude towards inclusive education compared to the teachers in the 40-50 age group with higher professional experience. In terms of specific requirement type, while Avramidis and Norwich (2002) stated that teacher attitudes were more supportive in the inclusion of students with sensory or physical disabilities in general education classes; MacFarlane and Woolfson (2013) revealed that teachers had negative attitudes in the education of students with emotional, social or behavioural disorders. When evaluated in 
terms of teachers' self-efficacy, a positive correlation was found between teachers' attitude towards inclusive education and self-efficacy in many studies (Hofman \& Kilimo, 2014; Yada \& Savolainen, 2017). On the other hand, in Malki and Einat's (2018) study, factors such as class size, number of students with special needs in the classroom and the use of information technologies in teaching were among the factors affecting teachers' attitude in inclusive practices.

In the study, related to the category of integration, it was concluded that it was important for students with special needs to share the same learning environment in an integrity without being separated from their peers in terms of cognitive, social and educational practices. In the category of understanding differences, it was concluded that students with special needs should have been accepted with their unique behaviours and characteristics and it was important to turn these differences into opportunities for the benefit of the students. In this regard, Odom et. al. (2012) stated that students with special needs made better academic progress in general education classes compared to differentiated classes. However, Buysse, Goldman, and Skinner (2002) demonstrated that inclusive education provided better results in terms of social acceptance, interaction, and peer education than other special education practices. In this context, inclusive education both tries to provide individuals with special needs the highest level of independent living skills and ensures the integration of the individual with society (Moran, 2007).

In summary, it was revealed that teachers considered inclusive education as a difficult, patience and exertion demanding process. In this process, teachers pointed to the importance of proper educational support that addressed the individual needs of the student. Teachers also emphasized that inclusive education was an indispensable need for students with special needs and they pointed out that it was important for teachers to display positive attitudes and behaviours towards students. In the research, findings overlapping the integration philosophy of inclusive education had also emerged. Accordingly, it had been concluded that it was important for students with special needs to share the same learning environment in an integrity without separating them from their peers who had 'normal' academic and social development. In addition, it was concluded that students with special needs should have been accepted with their own behaviours and characteristics in the learning environments they were in and it was important to turn these differences into opportunities for the benefit of the student.

\section{Conclusion}

When the results of the research are evaluated in general, it can be said that Turkish teachers know the basic philosophy of inclusive education and the general characteristics of the students with special needs academically and socially. However, it is known that there are deficiencies in the effective implementation of this education in classrooms and teachers are inadequate in this regard. Because Turkish teachers have knowledge on the subjects such as employing integrative practices, giving importance to individual differences, and providing appropriate educational support for the success of inclusive education. Yet, the applicability of this information in practice depends on the provision of some conditions in Turkish Education System. In this context, the awareness of school principals, teachers, parents, and other employees about children with special needs should be increased in order for inclusive education to be effective and the student with special needs to benefit from this application at the highest level. Then, teachers' insufficiency in knowledge and skills in recognizing the individual characteristics of the student with special needs and providing him/her appropriate educational support should be improved during undergraduate education and in-service training. Apart from these, problems such as crowded classes, physical insufficiency of schools and classes and lack of appropriate support services should be resolved in order to be successful in inclusive education in Turkey.

\section{Acknowledgments}

We would like to thank our participants who helped us with their valuable opinions in the emergence of the article. No potential conflict of interest was reported by the authors.

\section{References}

Abbott, L. (2006). Northern Ireland head teachers' perceptions of inclusion. International Journal of Inclusive Education, 10(6), 627-643. https://doi.org/10.1080/13603110500274379

Alver, B., Bozgeyikli, H., \& Işıklar, A. (2011). Psikolojik danışma ve rehberlik programı öğrencilerinin kaynaştırma eğitimine yönelik tutumlarının incelenmesi [Observation of attitudes of psychological counseling and guidance program students towards inclusive education]. Atatürk Üniversitesi Sosyal Bilimler Enstitüsü Dergisi, 15(1), 
$155-168$

Anderson, C. J., Klassen, R. M., \& Georgiou, G. K. (2007). Inclusion in Australia: What teachers say they need and what school psychologists can offer. School Psychology International, 28(2), 131-147. https://doi.org/10.1177/0143034307078086

Avramidis, E., \& Norwich, B. (2002). Teachers' attitudes towards integration/inclusion: A review of the literature. European Journal of Special Needs Education, 17(2), 129-147. https://doi.org/10.1080/08856250210129056

Avramidis, E., Bayliss, P., \& Burden, R. (2000). A survey into mainstream teachers' attitudes towards the inclusion of children with special educational needs in the ordinary school in one local education authority. Educational Psychology, 20(2), 191-211. https://doi.org/10.1080/713663717

Blanton, L. P., Pugach, M., \& Florian, L. (2011). Preparing general education teachers to improve outcomes for students with disabilities. Retrieved from https://www.ncld.org/wp-content/uploads/2014/11/aacte_ncld_recommendation.pdf

Borg, G., Hunter, J., Sigurjonsdottir, B., \& D’Alessio, S. (2011). Key principles for promoting quality in inclusive education.

Retrieved

from

https:/www.european-agency.org/sites/default/files/key-principles-for-promoting-quality-in-inclusive education key-principles-EN.pdf

Boyle, C., Topping, K., \& Jindal-Snape, D. (2013). Teachers' attitudes towards inclusion in high schools. Teachers and Teaching: Theory and Practice, 19(5), 527-542. https://doi.org/10.1080/13540602.2013.827361

Buysse, V., Goldman, B. D., \& Skinner, M. L. (2002). Setting effects on friendship formation among young children with and without disabilities. Exceptional Children, 68(4), 503-517. https://doi.org/10.1177/001440290206800406

Cole, D. A., \& Meyer, L. H. (1991). Social integration and severe disabilities: A longitudinal analysis of child outcomes. The Journal of Special Education, 25(3), 340-351. https://doi.org/10.1177/002246699102500306

Cologon, K. (2013). Inclusion in education: Towards equality for students with disability. Retrieved from http://dev.asksource.info/sites/asksource.info/files/13745\%20CDA\%20Issues\%20Paper\%20on\%20Inclusion_up dated_web_v21.pdf

De Boer, A., Pijl, S. J., \& Minnaert, A. (2011). Regular primary schoolteachers' attitudes towards inclusive education: A review of the literature. International journal of inclusive education, 15(3), 331-353. https://doi.org/10.1080/13603110903030089

Doğaroğlu, T., \& Dümenci, S. B. (2015). Sınıflarında kaynaştırma öğrencisi bulunan okul öncesi öğretmenlerin kaynaştırma eğitimi ve erken müdahale hakkındaki görüşlerinin incelenmesi. [Examining the opinions of pre-school teachers who have inclusion students in their classes about inclusive education and early intervention]. Hacettepe Üniversitesi Să̆lık Bilimleri Fakültesi Dergisi, 1(2), 460-473.

Farrell, P. (2000). The impact of research on developments in inclusive education. International Journal of inclusive education, 4(2), 153-162. https://doi.org/10.1080/136031100284867

Florian, L. (1998). An examination of the practical problems associated with the implementation of inclusive education policies. Support for learning, 13(3), 105-108. https://doi.org/10.1111/1467-9604.00069

Freeman, S. F., \& Alkin, M. C. (2000). Academic and social attainments of children with mental retardation in general education and special education settings. Remedial and Special Education, 21(1), 3-26. https://doi.org/10.1177/074193250002100102

Gök, G., \& Erbaş, D. (2011). Okulöncesi eğitimi öğretmenlerinin kaynaştırma eğitimine ilişkin görüşleri ve önerileri [Opinions and suggestions of preschool education teachers about inclusive education]. International Journal of Early Childhood Special Education, 3(1), 66-87.

Gözün, Ö., \& Yıkmış, A. (2004). Öğretmen adaylarının kaynaştırma konusunda bilgilendirilmelerinin kaynaştırmaya yönelik tutumlarının değişimindeki etkililiği [The effectiveness of informing preservice teachers about inclusion in the change of attitudes towards inclusion]. Ankara Üniversitesi Eğitim Bilimleri Fakültesi Özel Eğitim Dergisi, 5(2), 65-77.

Hofman, R. H., \& Kilimo, J. S. (2014). Teachers' attitudes and self-efficacy towards inclusion of pupils with 
disabilities in Tanzanian schools. Journal of Education and Training, 1(2), 177-198. https://doi.org/10.5296/jet.v1i2.5760

Karasu, T. (2019). Dkab öğretmenlerinin kaynaştırma eğitimi yeterlilikleri ile duygu, tutum ve kaygı düzeyleri arasındaki ilişki [The relationship between religious culture and ethics teachers' inclusive education competencies and emotion, attitude and anxiety levels]. Bilimname, 38(2), 501-522. https://doi.org/10.28949/bilimname.557699

Kargın, T., Güldenoğlu, B., \& Şahin, F. (2010). Genel eğitim sınıflarındaki özel gereksinimli öğrenciler için yapılması gereken uyarlamalara ilişkin sınıf öğretmenlerinin görüşlerinin incelenmesi [Opinions of the general education teachers on the adaptations for students with special needs in general education classrooms]. Kuram ve Uygulamada Eğitim Bilimleri, 10(4), 2431-2464.

Kauffman, J. M., Lloyd, J. W., Baker, J., \& Riedel, T. M. (1995). Inclusion of all students with emotional or behavioral disorders? Let's think again. Phi Delta Kappan, 76(7), 542.

Kayıl1, G., Koçyiğit, S., Doğru, S. S. Y., \& Çiftçi, S. (2010). Kaynaştırma eğitimi dersinin okul öncesi öğretmeni adaylarının kaynaştırmaya ilişkin görüşlerine etkisi [The effect of integrated education course on the opinions of prospective pre-school teachers about integrated education]. Mehmet Akif Ersoy Üniversitesi Eğitim Fakültesi Dergisi, 10(20), 48-65.

Koster, M., Pijl, S. J., Houten, E. V., \& Nakken, H. (2007). The social position and development of pupils with SEN in mainstream Dutch primary schools. European Journal of Special Needs Education, 22(1), 31-46. https://doi.org/10.1080/08856250601082265

Koh, M. S., \& Robertson, J. S. (2003). School reform models and special education. Education and Urban Society, 35(4), 421-442. https://doi.org/10.1177/0013124503255495

Kuhne, M., \& Wiener, J. (2000). Stability of social status of children with and without learning disabilities. Learning Disability Quarterly, 23(1), 64-75. https://doi.org/10.2307/1511100

Leavy, A. M., Mcsorley, F. A., \& Bote, A. L. (2007). An examination of what metaphor construction reveals about the evolution of preservice teachers' beliefs about teaching and learning. Teaching and Teacher Education, 23(7), 1217-1233. https://doi.org/10.1016/j.tate.2006.07.016

Loreman, T., \& Deppeler, J. (2002). Working towards full inclusion in education. Access: The National Issues Journal for People with a Disability, 3(6), 5-8.

MacFarlane, K., \& Woolfson, L. M. (2013). Teacher attitudes and behavior toward the inclusion of children with social, emotional and behavioral difficulties in mainstream schools: An application of the theory of planned behavior. Teaching and Teacher Education, 29, 46-52. https://doi.org/10.1016/j.tate.2012.08.006

Malki, S., \& Einat, T. (2018). To include or not to include-This is the question: Attitudes of inclusive teachers toward the inclusion of pupils with intellectual disabilities in elementary schools. Education, Citizenship and Social Justice, 13(1), 65-80. https://doi.org/10.1177/1746197917705138

Margalit, M., \& Efrati, M. (1996). Loneliness, coherence and companionship among children with learning disorders. Educational Psychology, 16(1), 69-79. https://doi.org/10.1080/0144341960160106

Marshall, J., Ralph, S., \& Palmer, S. (2002). 'I wasn't trained to work with them': Mainstream teachers' attitudes to children with speech and language difficulties. International Journal of Inclusive Education, 6(3), 199-215. https://doi.org/10.1080/13603110110067208

Martínez, R. S., \& Humphreys, L. A. (2006). The best choice. Principal Leadership, 6(5), 12-15.

Meijer, C. J. W. (2003). Special needs education across Europe. Middelfart: European Agency for Development in Special Needs Education.

Moberg, S. (2003). Education for all in the North and the South: Teachers' attitudes towards inclusive education in Finland and Zambia. Education and Training in Developmental Disabilities, 417-428.

Monteiro, E., Kuok, A. C., Correia, A. M., Forlin, C., \& Teixeira, V. (2019). Perceived efficacy of teachers in Macao and their alacrity to engage with inclusive education. International Journal of Inclusive Education, 23(1), 93-108. https://doi.org/10.1080/13603116.2018.1514762

Moran, A. (2007). Embracing inclusive teacher education. European Journal of Teacher Education, 30(2), 119-134. https://doi.org/10.1080/02619760701275578 
Norwich, B. (1994). The relationship between attitudes to the integration of children with special educational needs and wider socio-political views; an US-English comparison. European Journal of Special Needs Education, 9(1), 91-106. https://doi.org/10.1080/0885625940090108

Noyes, A. (2004). (Re) Producing mathematics teachers: A sociological perspective. Teaching Education, 15(3), 243-256. https://doi.org/10.1080/1047621042000257180

Odom, S. L., Buysse, V., \& Soukakou, E. (2012). Inclusion for young children with disabilities: A quarter century of research perspectives. Journal of Early Intervention, 33(4), 344-356. https://doi.org/10.1177/1053815111430094

Özel Eğitime Muhtaç Çocuklar Kanunu [Children with Special Educational Needs Law]. Retrieved from https://www.resmigazete.gov.tr/arsiv/18192.pdf

Özkubat, U., Sanır, H., Töret, G., \& Babacan, A. (2016). Yetersizlikten etkilenmiş çocukların sosyal kabullerini sağlamada kaynaştırmaya hazırlık etkinliklerinin etkisi [The impact of inclusion preparation activities on increasing social acceptance of children with disabilities]. Gazi Eğitim Bilimleri Dergisi, 2(3), 211-232.

Pavri, S., \& Luftig, R. (2001). The social face of inclusive education: Are students with learning disabilities really included in the classroom? Preventing School Failure: Alternative Education for Children and Youth, 45(1), 8-14. https://doi.org/10.1080/10459880109599808

Pearman, E. L., Huang, A. M., \& Mellblom, C. I. (1997). The inclusion of all students: Concerns and incentives of educators. Education and Training in Mental Retardation and Developmental Disabilities, 11-20.

Pit-ten Cate, I. M., Markova, M., Krischler, M., \& Krolak-Schwerdt, S. (2018). Promoting Inclusive Education: The Role of Teachers' Competence and Attitudes. Insights into Learning Disabilities, 15(1), 49-63.

Pivik, J., McComas, J., \& Laflamme, M. (2002). Barriers and facilitators to inclusive education. Exceptional children, 69(1), 97-107. https://doi.org/10.1177/001440290206900107

Rafferty, Y., Boettcher, C., \& Griffin, K. W. (2001). Benefits and risks of reverse inclusion for preschoolers with and without disabilities: Parents' perspectives. Journal of Early Intervention, 24(4), 266-286. https://doi.org/10.1177/105381510102400403

Ring, E., \& Travers, J. (2005). Barriers to inclusion: A case study of a pupil with severe learning difficulties in Ireland. European Journal of Special Needs Education, 20(1), 41-56. https://doi.org/10.1080/0885625042000319070

Rose, R. (2001). Primary school teacher perceptions of the conditions required to include pupils with special educational needs. Educational Review, 53(2), 147-156. https://doi.org/10.1080/00131910120055570

Saban, A. (2009). Öğretmen adaylarinin öğrenci kavramına ilişkin sahip oldukları zihinsel imgeler [Prospective teachers' mental images about the concept of student]. Türk Eğitim Bilimleri Dergisi, 7(2), 281-326.

Saban, A., Koçbeker, B. N., \& Saban, A. (2005). Öğretmen adaylarının öğretmen kavramına ilişkin sahip oldukları metaforlar [Prospective teachers' metaphors about the concept of teacher]. Paper presented at XIV. Educational Sciences Congress, Pamukkale University, Denizli, September 28-30.

Schmidt, M., \& Vrhovnik, K. (2015). Attitudes of teachers towards the inclusion of children with special needs in primary and secondary schools. Hrvatska revija za rehabilitacijska istraživanja, 51(2), 16-30.

Shanker, A. (1995). Full inclusion is neither free nor appropriate. Educational Leadership, 52(4), 18-21.

Shenton, A. K. (2004). Strategies for ensuring trustworthiness in qualitative research projects. Education for Information, 22(2), 63-75.

Sloper, T., \& Tyler, S. (1992). Integration of children with severe learning difficulties in mainstream schools: evaluation of a pilot study. Educational and Child Psychology, 9(4), 34-45.

Smith, M. K., \& Smith, K. E. (2000). "I believe in inclusion, but...": Regular education early childhood teachers' perceptions of successful inclusion. Journal of Research in Childhood Education, 14(2), 161-180. https://doi.org/10.1080/02568540009594761

Smith, T. E., Polloway, E. A., Patton, J. R., \& Dowdy, C. A. (2014). Teaching students with special needs in inclusive settings (6th ed.). Boston: Pearson.

Sönmez, N., Alptekin, S., \& Bıçak, B. (2019). Okul öncesi eğitim öğretmenlerinin kaynaştırma eğitiminde 
yeterliliklerini artırmaya yönelik geliştirilen hizmetiçi eğitim programının etkisi [The effect of in-service education program developing for improving competences of preschool teachers in the inclusive education]. İönü Üniversitesi Ĕ̈itim Fakültesi Dergisi, 20(2), 439-456.

Toy, S. N., \& Duru, S. (2016). Sınıf öğretmenlerinin öğretmen öz yeterlikleri ile kaynaştırma eğitimine ilişkin yeterlik inançlarının karşılaştırılması [The comparison of self-efficacy and inclusive education beliefs of primary school teachers]. Ege Eğitim Dergisi, 17(1), 146-173. https://doi.org/10.12984/eed.00332

Uditsky, B. (1993). From Integration to Inclusion: The Canadian Experience. In R. Slee (Ed.), is there a desk with my name on it? The politics of integration. USA: Falmer Press.

Uysal, A. (2004). Kaynaştırma uygulamaları yapan öğretmenlerin kaynaştırmaya ilişkin görüşleri [Opinions of teachers engaged in inclusion practices on inclusion]. Özel Eğitimden Yansimalar [Reflections from Special Education]-in 13th National Special Education Congress Proceedings, 12-14.

Watkins, A. (2012). Teacher education for inclusion: Profile of inclusive teachers. Retrieved from https://www.european-agency.org/sites/default/files/Profile-of-Inclusive-Teachers.pdf

Wiener, J., \& Harris, P. J. (1989). Peer Relations of Learning Disabled Children: A Reciprocity Model. Canadian Journal of Special Education, 5(2), 123-134.

Yada, A., \& Savolainen, H. (2017). Japanese in-service teachers' attitudes toward inclusive education and self-efficacy for inclusive practices. Teaching and Teacher Education, 64, 222-229. https://doi.org/10.1016/j.tate.2017.02.005

Yıldırım, A., \& Şimşek, H. (2008). Sosyal bilimlerde nitel araştırma yöntemleri [Qualitative research methods in the social sciences] (6th ed.). Ankara: Seçkin Yayıncılık

\section{Copyrights}

Copyright for this article is retained by the author(s), with first publication rights granted to the journal.

This is an open-access article distributed under the terms and conditions of the Creative Commons Attribution license (http://creativecommons.org/licenses/by/4.0/). 